\title{
Explaining Pakistan's Premature Deindustrialization
}

\author{
Nazia Nazeer* and Rajah Rasiah**
}

\begin{abstract}
Recognizing that Pakistan faces premature deindustrialization, this paper seeks to explain the phenomenon. The country experienced wild swings in industrialization during the 1950s and 1960s. The period 2001-10 was characterized by fairly strong growth, followed by contractions in other periods. Pakistan's manufacturing sector is dominated by clothing and textiles exports. Periods of manufacturing growth were associated with pro-manufacturing and import substitution policies, while slumps were characterized by deregulation and a relatively high exchange rate. The evidence shows that the relative stagnation of manufacturing (regardless of the policies implemented) can be explained by the lack of a dynamic industrial policy targeting technological catch-up and leapfrogging. Moreover, where rents were distributed in the form of incentives, there was no emphasis on monitoring and appraisal.
\end{abstract}

Keywords: Deindustrialization, industrial policy, economic growth, Pakistan.

JEL classification: L52.

\section{Introduction}

Deindustrialization, which has gained substantial traction among scholars since the 1980s, is sometimes viewed as the cause of diverging per capita incomes between developed countries (Rowthorn \& Wells, 1987). In the past, deindustrialization was considered to occur when the share of value-added in GDP and that of manufacturing employment in total employment began to fall (Kaldor, 1967). However, the proliferation of automation and machinery in manufacturing has reduced the significance of employment as a measure of deindustrialization. Thus, the share of manufacturing employment in total employment is likely to drop before a commensurate fall in the share of manufacturing value-added in GDP. Rasiah (2011) argues that deindustrialization is characterized by a fall in the GDP share of industry value-added in general and of manufacturing

\footnotetext{
* Department of Development Studies, University of Malaya, Malaysia.

** Department of Development Studies, University of Malaya, Malaysia.
} 
value-added in particular, rather than by a fall in the share of manufacturing employment in total employment.

Positive deindustrialization occurs as a result of the falling share of manufacturing in GDP while manufacturing productivity continues to rise. This type of deindustrialization is inevitable even among countries experiencing rapid technological change and productivity growth as production shifts to more capital-intensive and knowledge-intensive activities. Negative deindustrialization, which is undesirable, occurs when the share of manufacturing in GDP falls in the face of falling manufacturing productivity (Rowthorn \& Wells, 1987).

Rasiah (2011) defines premature deindustrialization as the falling share of manufacturing in GDP, accompanied by low manufacturing productivity growth when manufacturing industries have yet to mature technologically. This type of deindustrialization is a pathological phenomenon, where simple disequilibrium restricts the economy from fulfilling its development potential. Premature deindustrialization entails not only the falling share of manufacturing in GDP, but also a downward structural shift from high-value-added to low-value-added economic activities or manufacturing stagnation in the latter. In Malaysia, this occurred as a consequence of the substantial import of low-skilled foreign labor into the manufacturing sector.

The most severe form of negative deindustrialization arises in lowincome and middle-income economies when manufacturing contracts prematurely and is still characterized by low-value-added activities, declining productivity, stagnant output growth and shrinking jobs. When such countries experience negative deindustrialization that is accompanied by either a contraction or slowdown in the growth of per capita income, they become vulnerable to undesirable structural change as they are trapped in low-productivity services.

Indeed, many countries in Asia, Africa and Latin America have experienced an expansion in low-productivity services, which offer little potential for long-term growth. Such premature deindustrialization is a threat to sustained economic growth in low- and middle-income countries on two counts. First, such countries have appropriated few of the 'growthenhancing' benefits of manufacturing. Second, manufacturing tends to be replaced by unproductive rather than productive services, including informal services. 
In contrast, when 'mature' or positive deindustrialization sets in, the shift toward productive services helps to build knowledge-synergizing linkages characterized by technological upgrading and productivity increments (Rowthorn \& Wells, 1987; Kollmeyer, 2009; Rasiah, 2011). It is only then that the services sector becomes an engine of growth: its growth stimulates not only the sector's own expansion, but also that of the other sectors in the economy. Such policies are likely to deindustrialize the economy. Both the deregulation of tariffs too quickly, without giving manufacturing the time to restructure, as well as the continued application of protection and other forms of rent without stringent performance standards to drive technological upgrading contribute substantially to deindustrialization (Rasiah \& Nazeer, in press).

With a population of 188.9 million in 2015, Pakistan has been saddled with serious political security problems, a number of which remain unresolved. This is partly to blame for its economic stagnation. After showing some promise during Ayub Khan's military regime in the 1950s and 1960s, the country started to deindustrialize prematurely in the 1970s although it showed some signs of growth in the late 1990s until 2006. Pakistan is the world's fourth largest producer of cotton and chief exporter of yarn. Several factors have restricted manufacturing expansion in the country: (i) poor basic infrastructure (including power supply and transport networks), (ii) weak high-tech infrastructure (including the lack of incentives for R\&D and weak university-industry links) and (iii) inadequate integration with the external economy (customs coordination, exchange rate appreciation caused by remittances from abroad and huge inflows of cheap imports).

While, on one hand, the institutional infrastructure for manufacturing is not conducive to expansion, on the other hand, Pakistan has never had a profound industrial policy targeted at stimulating technological upgrading. The industrial policy implemented under the Ayub Khan regime was led by import-substituting industrialization. This was characterized by high real effective protection rates - low tariffs on raw materials, intermediate goods and capital goods, but high tariffs on final goods - without any emphasis on monitoring and disciplining infant firms so that they might reach the technology frontier.

Lacking the monitoring and appraisal instruments to tie rents to technological upgrading as done in South Korea (Amsden, 1989) and Taiwan (Fransman, 1985), the 1960s saw the creation of an industrial class that could not upgrade to high value-added activities. In addition, the 
administration of tariffs, bureaucratic control and several modes of licensing to control entry into industries exacerbated red tape (the license raj'), thereby reducing the efficiency and competitiveness of manufacturing industries (Devarajan \& Nabi, 2006). While Pakistan's efforts to dump industrial policy are argued to have been a disastrous mistake by some scholars (see Hamid \& Khan, 2015; Haque, 2015), the lack of a sound framework to stimulate technological upgrading in the 1950s and 1960s suggests that it would not have lasted long: it would have been a drain on the country's foreign exchange resources, as happened in Malaysia and the Philippines in the 1950s and 1960s (Rasiah, 2009).

This paper aims to explain why Pakistan has deindustrialized prematurely, to extend the succinct analyses begun by Hamid, Nabi and Zafar (2014), Haque (2015) and Hamid and Khan (2015). The next section presents some theoretical considerations to locate the analysis. Section 3 discusses government policies that either stimulated or undermined industrialization in Pakistan. Section 4 examines the structure of GDP and the growth of manufacturing, trade and productivity trends in Pakistan's manufacturing sector. Section 5 concludes the study.

\section{Theoretical Considerations}

The idea of industrialization was advanced by Smith (1776) and Young (1928) as being important to support economic progress, given its capacity to stimulate the differentiation of economic activities, thereby extending the division of labor and increasing returns. Gerschenkron (1962), Abramovitz (1956), Chang (2003) and Reinert (2007) document how the process of industrialization transformed today's developed countries. Technological catch-up through learning and innovation has been central to successful industrialization in Germany, the US, Japan, South Korea and Taiwan.

As latecomers, Japan, South Korea and Taiwan sought to catch up by providing protection and subsidies to support the acquisition of knowledge from the more developed countries in the industries they were promoting (Amsden, 1991). Not all countries implementing industrial policy managed to become developed. Countries that did not do so well either had governments captured by clientelist interests, which resulted in the dissipation of rents created through protection, subsidies and grants, or did not introduce a sound policy to stimulate technological upgrading. 
The Philippines and Indonesia are examples of countries that had industrial policies until the 1980s and 2000, respectively, but were simply undermined by their instrumental alignment with clientelists. Recent latecomers that developed successfully through industrial policy, such as South Korea and Taiwan, not only offered protection, subsidies and grants to national firms, but also launched a proactive technological catch-up policy. Stringent evaluation, monitoring and appraisal and quick termination of rents to dissipaters ensured rapid technological catch-up and upgrading from low- to high-value-added manufacturing activities in Japan, South Korea and Taiwan (Johnson, 1982; Amsden, 1989; Wade, 1990).

While the drivers of economic progress are now well documented, albeit not in a way that new latecomers can track easily, not much is clear about negative and premature deindustrialization. Deindustrialization is generally said to occur when there is a long-term declining trend in the contribution of manufacturing in particular and (with its appendages of utilities and construction) of industry in general (Kaldor, 1967). This decline is normally measured by a fall in the share of manufacturing valueadded in GDP and/or a fall in the share of manufacturing employment in total employment. While positive deindustrialization is desirable, as manufacturing productivity drives the growth of value-added in other sectors, negative deindustrialization is undesirable because it undermines structural change from low- to high-value-added activities.

As noted in the introduction, premature deindustrialization is also undesirable as the manufacturing sector's contribution to the economy begins to decline before it has matured. The consequences of premature deindustrialization have a negative impact on economic growth and structural change. First, a decline in the sector's productivity will reduce its competitiveness in the international economy. Second, the premature transfer of employment from manufacturing to services may reduce wages. Third, the falling competitiveness of manufacturing may aggravate balance-of-payments problems.

The lack of an effective industrial policy to stimulate technological upgrading is central to why countries face premature deindustrialization (Rasiah, 1995; Lall, 2000). Indeed, for developing countries, moving forward becomes increasingly difficult as the international trading system becomes more liberal (Lall, Weiss \& Zhang, 2005). Burgeoning balance-ofpayments problems can aggravate government finances so as to undermine a country's capacity to pay for essential services such as health and education. 
Successful industrializers such as South Korea and Taiwan achieved rapid industrialization by targeting economic diversification from low- to high-value-added activities - both within industries and by shifting to other industries (Amsden, 1989; Wade, 1990). While Amsden suggests getting relative prices wrong to stimulate technological catch-up, Rodrik (2007) emphasizes the opposite. Amsden (1989) is right in arguing that South Korea departed from the orthodoxy prevailing in World Bank and International Monetary Fund circles to introduce and finance heavy and high-tech industries in which it enjoyed no comparative advantage in the 1970s. Instead, relative prices were manipulated through subsidies on loans and tariffs on imports to give infant national firms space to mature. Stringent performance standards through export quotas were applied to reduce the dissipation of these rents.

Hence, we seek to examine efforts to promote industrialization in Pakistan, especially if instruments such as protection using tariffs and subsidies and technological upgrading were used by the government. Three aspects of the government's role are important: the provision of rents in the form of tariffs and subsidies, the introduction of technological catchup milestones and appraisal mechanisms to ensure that rents translate into industrial upgrading. Since Pakistan has begun deindustrializing prematurely, we focus on whether any or all of the above were poorly executed. One would expect Pakistan's misfiring manufacturing sector to have faced little transformation from low- to high-value-added economic activities in output and exports or even a shift from consumer and intermediate goods to capital goods.

\section{Industrial Policy}

Pakistan's industrial policies are characterized by different phases and have been an integral part of the country's five-year development plans. Burki (2008) traces five industrial policies launched in Pakistan, the impact of which is evident in the performance of the manufacturing sector.

While the Ayub Khan government confronted various conflicts and grappled with the political and economic organization of the country in the 1950s, Pakistan enjoyed a sensational pace of growth in manufacturing. Production and investment in large-scale manufacturing grew by 20 percent in the period 1950-55. The strong growth continued in the 1960 s as manufacturing grew by 10 percent per annum on average during 1960-70 (Abbasi, 2009). The focus then was on import substitution through tariff protection. 
However, the populist Bhutto government that was elected toward the end of the 1960s began a nationalization program in the manufacturing sector. The government was short-lived and overthrown by the military in 1977. The new regime began economic deregulation, which undermined the import-substituting industries so that manufacturing grew on average by only 5.4 percent per annum over 1970-80. Nevertheless, manufacturing grew on average by 8.2 percent per annum in the 1980s (Zaidi, 2005). The causes and consequences of this growth had mixed effects for Pakistan.

The military government under Zia-ul-Haq, which lasted till 1988, abandoned both state capitalism and state socialism to pursue Islamization and the redistribution of economic rents (Sayeed, 1995). The marketfriendly policies of deregulation, de-control and denationalization were introduced to stimulate private investment. The influence of the military in the economy increased as army officers were appointed to key positions (Khan, 2000; Noman, 1988). Import substitution was abandoned as tariffs were lowered and flexible exchange rates introduced. Controls on the capital account and public enterprises were also removed.

These reforms helped stimulate industrial exports from industrial zones as the production of steel, cement, fertilizer and vehicles began to rise. The public steel mill began production in 1982 and reached its highest capacity operation in 1984/85. Attractive incentives through direct export subsidies on customs duties and sales tax were introduced in 1978/79 to help stimulate manufactured exports. The investment environment also improved as the government gave assurances against future nationalization and offered other tax concessions. Consequently, manufacturing grew by 9.5 percent per annum in the period 1978-83. The private sector's share in new industrial investment had risen to over 90 percent by 1988 compared to about 25 percent in 1976/77.

The restoration of private industrial investment privileges also aided an upsurge in the production of traditional industries such as cotton textiles and cement. The textiles and clothing sector received priority due to its low gestation and instant profit-making potential. However, the structure of incentives did not condition value addition, so that cotton yarn remained a major export despite receiving substantial subsidies (Nadvi \& Sayeed, 2004; Hasan, 1998). Whereas exports of grey fabric and cotton yarn expanded sharply to make the industry the main employer in the country, the lack of upgrading policies confined it to low-wage, low-productivity activities (Nadvi \& Sayeed, 2004). 
Indeed, such an input-driven framework generated a severe drain on Pakistan's reserves, which aggravated the fiscal and current account deficits in the 1980s. Increased military expenditure exacerbated the country's public debt. Defense spending rose by 9 percent per annum to an average of 6.5 percent of GDP, while development spending grew by 3 percent per annum in this period. Manufacturing growth slowed down in the 1990s not only because the provision of generous incentives could not be sustained, but also because the lack of technological policies restricted industrial upgrading from low- to high-value-added activities.

Except in 1997/98, when a reduction in sales tax, credit provision, tariff rationalization and better sugarcane production increased manufacturing growth slightly to 5.5 percent per annum (Kemal, 2004), the large government expenditures in the earlier period restricted further manufacturing growth. Average annual manufacturing growth fell to 3.5 percent per annum in the early 1990s. Along with stagnation in agriculture, the slowdown in manufacturing resulted in a sharp drop in GDP growth after 1988 as inflation and poverty escalated.

The most serious effects of this culminated in 1993 and 1996 when Pakistan faced a foreign exchange crisis. Unfortunately, the subsequent governments under Benazir Bhutto and Nawaz Sharif were either unwilling or unable to halt the decline. A sharp fall in foreign remittance inflows between 1987 and 1990, precipitated by the Gulf War, aggravated Pakistan's current account deficit, although it enjoyed reasonable growth in exports.

The devaluation of the Pakistani rupee and improved incentives aided export growth and a contraction in imports (Sarmad, 1992, p. 866). Falling remittances from overseas workers were substituted for by other sources, including inflows of funds held overseas by Pakistani nationals and nonresident Pakistanis as they were allowed to open foreign currency accounts in Pakistani banks. These accounts were freed from income and wealth taxes and those holding foreign currency accounts were also allowed to obtain rupee loans against such accounts (Khan et al., 2005). Consequently, between June 1991 and June 1996, Pakistan had \$4 billion flow into its foreign exchange accounts (Wizarat, 2002, p. 27).

Between 2000 and 2005, manufacturing enjoyed a strong average annual growth rate of 10 percent per annum (Table 1). Similar to the Zia-ulHaq regime, General Pervez Musharraf's government, which took power in October 1999, introduced a decentralization and deregulation strategy to 
stimulate economic growth. ${ }^{1}$ Falling tariffs and tariff bands were accompanied by initiatives to access export markets in the European Union (EU). Increased liquidity in the economy generated by a large rise in remittances from abroad and foreign direct investment inflows drove consumption-led energy-intensive growth (see Amjad, Din \& Qayyum, pp. 13-30).

Table 1: Sectoral GDP growth, \%

\begin{tabular}{lccccc}
\hline Sector & $\mathbf{1 9 8 6 - 9 0}$ & $\mathbf{1 9 9 1 - 9 5}$ & $\mathbf{1 9 9 6 - 2 0 0 0}$ & $\mathbf{2 0 0 1 - 0 5}$ & $\mathbf{2 0 0 6 - 1 0}$ \\
\hline Agriculture & -5.8 & 1.6 & 1.6 & -10.8 & 3.9 \\
Industry & 8.2 & -3.9 & -3.7 & 12.9 & -5.6 \\
Mining and quarrying & 0.0 & -28.6 & -28.3 & 11.1 & -16.1 \\
Manufacturing & 6.9 & 4.5 & 3.2 & 10.0 & 4.2 \\
Construction & 2.4 & -14.3 & -32.4 & 4.2 & 0.0 \\
Electricity and gas distribution & 21.7 & -2.9 & 0.0 & -8.8 & 23.8 \\
Services & -0.4 & 3.1 & 0.6 & -1.0 & 1.1 \\
Transport, storage and & -9.1 & 18.6 & 17.7 & -5.3 & 3.2 \\
communication & & & & & \\
Wholesale and retail trade & 9.0 & -1.2 & 2.4 & 1.7 & -0.6 \\
Finance and insurance & -12.5 & 13.3 & 8.8 & 30.0 & -13.7 \\
Public administration & 1.1 & -7.1 & -24.4 & -6.7 & -5.3 \\
Others & -3.2 & 4.2 & 0.0 & -4.1 & 11.1 \\
\hline
\end{tabular}

Source: Pakistan Economic Survey (various years).

Pakistan's integration with EU markets quickened following the introduction of duty-free access to clothing items as countries adjusted their fiscal system in line with the termination of the Multi-Fiber Agreement (MFA) in 2004 (Rasiah, 2012). Import duties of around 12 percent had been levied on clothing imports from Pakistan in the EU until January 2005.

The government focused on small and medium enterprises (SMEs) to create jobs and raise income. The Musharraf government also launched major industrial parks in Landhi (Karachi), M3 (Faisalabad) and Sundar (Lahore). While pursuing market fundamentals, Pakistan's industrial strategy in the period 2001-05 emphasized product diversification, which stimulated growth in that sector. The share of industry in GDP increased from 22.6 percent in 2000 to 26.7 percent in 2006 , growing by double digits

\footnotetext{
1 "The economic charge-sheet." (12 August 2008). Dawn. Available at http://dawn.com/2008/08/12/op.htm\#1.
} 
annually. As a consequence, the national economy grew by 7 percent in this period (Pakistan Economic Survey for 2004-06).

However, both manufacturing growth as well as economic growth cooled down in the subsequent period, 2006-10. The slowdown can be attributed to the worsening security situation in the country as civil rights were undermined and terrorist attacks surged (Looney, 2008). The rising cost of gas and electricity, following the global rise in oil prices, and the global financial crisis of 2007/08 affected Pakistan's economy adversely. Devastating energy shortages and large-scale load-shedding had a serious effect on manufacturing. A few enterprises such as the Nishat Group switched to capital-intensive, but less power-intensive, production. Indeed, almost all large firms completed an energy audit and have since taken measures to reduce the use of power. Textile mills and engineering firms have, consequently, managed to save between 15 and 20 percent of power. ${ }^{2}$ Above all, the country's leading exports, textiles and clothing, fell in 2006/07, which aggravated the trade balance.

Pakistan's patchy economic performance is a result of the absence of a dynamic industrial policy led by technological upgrading (Rasiah \& Nazeer, 2015). Over time, a large cluster of potential entrepreneurs has grown in Pakistan, demonstrating the ability to expand private investment. Moreover, the public sector-driven industries of fertilizer, steel, cement, automotive equipment, petroleum refining and petrochemicals have continued to service the national economy. In addition, the government has established development finance institutions and the Corporate Industrial and Restructuring Corporation to help industry grow in spite of tough competition in the global market. A number of institutions have been set up to fulfil the needs and demands of industry. ${ }^{3}$ SMEs play a significant role in manufacturing, which contribute 30 percent to GDP. They generate a quarter of the manufacturing sector's export earnings. ${ }^{4}$

Despite having established a strong science base, Pakistan has not linked this proactively to its industrial policy in order to transform the manufacturing sector from low- to high-value-added activities. Over 1947-

2 “Industry still lagging behind." (7 December 2015). The News. Available at http://e.thenews.com.pk/newsmag/mag/detail_article.asp?id=4844\&magId=10

3 The National Development Finance Corporation, Industrial Development Bank of Pakistan, Pakistan Industrial Credit and Investment Corporation, Agricultural Development Bank of Pakistan, the former Bankers Equity Limited, the Small Business Finance Corporation and the Regional Development Finance Corporation.

4 "Industrialization in Pakistan." (7 January 2002). Dawn. Available at http://www.dawn.com/news/13697/industrialization-in-pakistan 
2010, manufacturing has enjoyed double-digit growth for short periods, but at no time has it demonstrated the potential to catch up with and leapfrog over the world's leading manufacturing firms. Indeed, Pakistan has experienced premature deindustrialization as its manufacturing share in GDP fell from 18.6 percent in 2005 to 14 percent in 2013 when it is still characterized by low-end activities. A comparison of its manufacturing performance with that of the East Asian economies can be found in Rasiah and Nazeer (in press).

\section{Manufacturing Performance}

The dramatic shifts in the nature of industrial policy instruments used - albeit starting with a small base, launched ad hoc and without a clear roadmap for catching up - are mirrored by the huge swings in manufacturing growth, trade balance coefficients and relative stagnation technologically. This section examines the performance of manufacturing industries in Pakistan over the period 1981-2010.

\subsection{Value Added}

In the key industry of textiles and clothing, value-added contracted in the periods 1981-85, 1991-95 and 2001-05 (Table 2). The focus on domestic industry in the early 1980s led to an expansion in the production of chemicals and machinery and transport equipment, which grew on average by 33.3 and 25.0 percent per annum, respectively, in 1981-85. The latter industry also grew strongly in 2001-05 as demand rose sharply due to a large inflow of remittances from abroad, following generous incentives offered by the government. Despite its small starting base, food, beverages and tobacco production either contracted or grew slowly during 1981-2010.

Table 2: Annual average manufacturing value-added growth, \%

\begin{tabular}{lcccccc}
\hline Sector & $\mathbf{1 9 8 1 - 8 5}$ & $\mathbf{1 9 8 6 - 9 0}$ & $\mathbf{1 9 9 1 - 9 5}$ & $\mathbf{1 9 9 6 - 2 0 0 0}$ & $\mathbf{2 0 0 1 - 0 5}$ & $\mathbf{2 0 0 6 - 1 0}$ \\
Chemicals & 33.3 & 6.3 & 6.7 & 6.3 & -17.6 & \multicolumn{1}{c}{0.0} \\
Food, beverages and tobacco & -8.6 & -20.0 & 4.5 & -8.7 & 4.8 & 4.5 \\
Textiles and clothing & -9.5 & 28.6 & -10.0 & 19.2 & -18.2 & 37.5 \\
$\begin{array}{l}\text { Machinery and transport } \\
\text { equipment }\end{array}$ & 25.0 & 0.0 & -20.0 & 0.0 & 40.0 & -37.5 \\
Total manufacturing & 9.5 & 6.9 & 4.5 & 3.2 & 10.0 & 4.2 \\
\hline
\end{tabular}

Source: Authors' calculations based on data from the World Development Indicators. 


\subsection{Exports}

Pakistan's manufactured exports in low-tech, medium-tech and high-tech industries enjoyed higher growth in 2000-13 than in 1990-2000 (Figure 1). The medium-tech and high-tech industries experienced higher growth in exports than low-tech industries (Rasiah \& Nazeer, 2015). However, this was not only a consequence of their low starting base: the industries involved are concentrated in the low-value-added segments of manufacturing. Pakistan's textiles and clothing industry remained the foundation of export manufacturing, accounting for 44.2 percent of exports in 2005 and 37.1 percent of exports in 2013.

Figure 1: Annual average manufactured export growth, 1990-2013

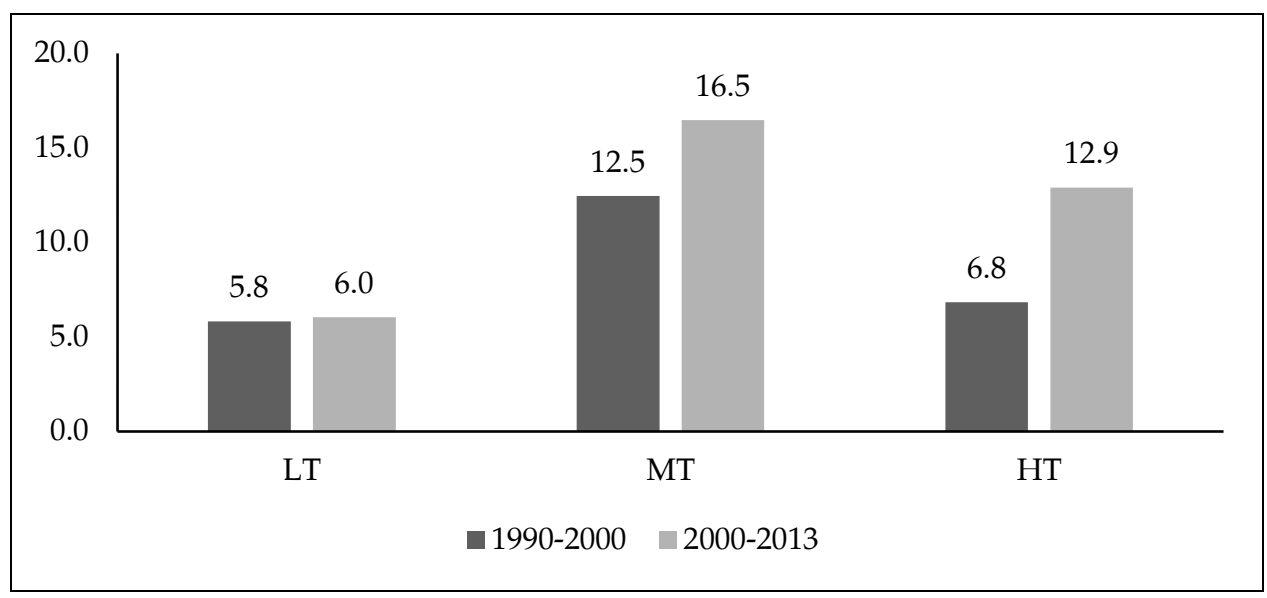

Note: $\mathrm{LT}=$ low-technology, MT = medium-technology, HT = high-technology. Source: Compiled from UN Comtrade database.

\subsection{Trade Balance}

Pakistan's low export performance is ascribed to the structure of its exports, which is characterized by heavy specialization in traditional items, an inability to diversify and upgrade in the value chain and the lack of complementary support from knowledge-intensive services (Haque, 2014). Clothing and textiles is the only industry in which Pakistan has enjoyed a strong, positive trade balance over the period 2000-15 (Table 3). While foods had a positive trade balance over the period 2001-10 before falling into negative figures in 2011-15, all other industries experienced a negative trade balance during 2001-15. Meanwhile, foods, machinery and equipment and other manufactures experienced a trend decline in their trade balance over the period 2001-15. 
Table 3: Manufacturing trade balance, 2000-15

\begin{tabular}{lccc}
\hline Industry & $\mathbf{2 0 0 0 - 0 5}$ & $\mathbf{2 0 0 6 - 1 0}$ & $\mathbf{2 0 1 1 - 1 5}$ \\
\hline Foods & 0.028 & 0.011 & -0.020 \\
Clothing and textiles & 0.667 & 0.712 & 0.698 \\
Petroleum & -0.908 & -0.879 & -0.860 \\
Chemicals & -0.681 & -0.715 & -0.690 \\
Machinery and transport equipment & -0.881 & -0.909 & -0.930 \\
Other manufactures & -0.034 & -0.087 & -0.180 \\
\hline
\end{tabular}

Source: State Bank of Pakistan and Pakistan Economic Survey (various years).

All in all, we can see that the use of industrial policies lacking any serious focus on technological deepening is reflected in the relative stagnation of the manufacturing sector in Pakistan. Indeed, except for the natural endowment supported clothing and textiles sector, all other manufacturing industries experienced slow growth in value-added and exports and a negative trade balance.

\section{Conclusion}

It appears that Pakistan enjoyed its highest manufacturing growth when (i) import substitution policies were implemented, (ii) favorable incentives were given to manufacturing establishments, (iii) the external environment (especially one that attracted a high volume of remittances) was conducive to growth or (iv) the MFA quotas were removed in 2004. The worst years appear to be when liberalization was introduced (see Haque, 2015). Unlike typical resource-rich countries, Pakistan's manufacturing sector has also been adversely affected by the Dutch disease phenomenon arising from high exchange rate valuations caused by remittances from abroad.

Despite these achievements, the pace of Pakistan's manufacturing growth, even in peak periods (the 1950s and 1960s and 2006-10), was far behind that of the Republic of Korea, Taiwan and China (Rasiah \& Nazeer, in press). The manufacturing sector has not only grown slowly, but its share of GDP has also contracted prematurely since 2010, owing to industrial policies that did not emphasize technological deepening. Except for clothing and textiles, which have a strong natural support base, all other manufacturing industries have experienced slow growth in valueadded and exports and a negative trade balance since 2011. 
Clearly, Pakistan is facing premature deindustrialization. Its economic problems are also tied to the nature of its power relations, which has restricted institutional change. The experience of Pakistan does not contradict the conventional wisdom that political strength and stable regimes are favorable to the course of economic development in developing nations. Pakistan's tense relations with India have had a significant negative impact on the country's political, monetary and social environments. This has given the military considerable political clout, aggravated by US military aid (Hasan, Kemal \& Naseem, 1997).

Rather than focusing on industrial diversification and building competitiveness internationally through the creation and diversion of rents to support technological catch-up, government policy has been shaped by clientelist interests. The solution for Pakistan is to focus on developing its technological capabilities to stimulate industrial structural change from low- to high-value-added activities. 


\section{References}

Abbasi, Z. F. (2009). Analysis of the political economy of industrial policy in Pakistan. Islamabad: Impact Consulting.

Abramovitz, M. (1956). Resource and output trends in the United States since 1870. American Economic Review, 46(2), 5-23.

Amjad, R., Din, M., \& Qayyum, A. (2011). Pakistan: Breaking out of stagflation into sustained growth [Special edition]. Lahore Journal of Economics, 16, 13-30.

Amsden, A. H. (1989). Asia's next giant: South Korea and late industrialization. New York: Oxford University Press.

Amsden, A. H. (1991). Diffusion of development: The late-industrializing model and greater East Asia. American Economic Review, 81(2), 282-286.

Burki, S. J. (2008). Industrial policy: Domestic challenges, global imperatives and Pakistan's choices [Special edition]. Lahore Journal of Economics, 13, 23-34.

Chang, H.-J. (2003). Kicking away the ladder: Development strategy in historical perspective. London: Anthem Press.

Devarajan, S., \& Nabi, I. (2006). Economic growth in South Asia: Promising, un-equalizing, sustainable? Economic and Political Weekly, 41(33), 3573-3580.

Fransman, M. (1985). Conceptualizing technical change in the Third World in the 1980s: An interpretive survey. Journal of Development Studies, 21(4), 572-652.

Gerschenkron, A. (1962). Economic backwardness in historical perspective. Cambridge, MA: Belknap Press.

Hamid, N., \& Khan, M. (2015). Pakistan: A case of premature deindustrialization? [Special edition]. Lahore Journal of Economics, 20, 107-141. 
Hamid, N., Nabi, I., \& Zafar, R. (2014). The textiles and garments sector: Moving up the value chain [Special edition]. Lahore Journal of Economics, 19, 283-306.

Haque, I. (2014). Toward a competitive Pakistan: The role of industrial policy [Special edition]. Lahore Journal of Economics, 19, 61-90.

Haque, I. (2015). Theory at odds with best practice: The travails of industrial policy [Special edition]. Lahore Journal of Economics, 20, 87-106.

Hasan, P. (1998). Pakistan's economy at the crossroads: Past policies and present imperatives. Karachi: Oxford University Press.

Hasan, P., Kemal, A. R., \& Naseem, S. M. (1997). Learning from the past: A fifty-year perspective on Pakistan's development [with comments]. Pakistan Development Review, 36(4), 355-402.

Johnson, C. (1982). MITI and the Japanese miracle: The growth of industrial policy, 1925-1975. Stanford, CA: Stanford University Press.

Kaldor, N. (1967). Strategic factors in economic development. Ithaca, NY: Cornell University Press.

Kemal, A. R. (2004). Exploring Pakistan's regional economic cooperation potential. Pakistan Development Review, 43(4), 313-334.

Khan, M. H. (2000). Rent-seeking as process. In M. H. Khan \& K. S. Jomo (Eds.), Rents, rent-seeking and economic development: Theory and evidence in Asia. Cambridge: Cambridge University Press.

Khan, M. A., Qayyum, A., Sheikh, S. A., \& Siddique, O. (2005). Financial development and economic growth: The case of Pakistan. Pakistan Development Review, 44(4), 819-837.

Kollmeyer, C. (2009). Explaining deindustrialization: How affluence, productivity growth and globalization diminish manufacturing employment. American Journal of Sociology, 114(6), 1644-1674.

Lall, S. (2000). The technological structure and performance of developing country manufactured exports, 1985-98. Oxford Development Studies, 28(3), 337-369. 
Lall, S., Weiss, J., \& Zhang, J. (2005). The 'sophistication' of exports: A new measure of product characteristics (QEH Working Paper No. 123). Oxford: Oxford University.

Looney, R. (2008). The Musharraf paradox: The failure of an economic success story. Open Area Studies Journal, 1, 1-15.

Nadvi, K., \& Sayeed, A. (2004). Industrial capital and pro-poor change. Unpublished report prepared for DFID.

Noman, O. (1988). Pakistan: A political and economic history since 1947. London: Kegan Paul International.

Rasiah, R. (1995). Foreign capital and industrialization in Malaysia. Basingstoke: Macmillan.

Rasiah, R. (2009). Garment manufacturing in Cambodia and Laos. Journal of the Asia Pacific Economy, 14(2), 150-161.

Rasiah, R. (2011). Is Malaysia facing negative deindustrialization? Pacific Affairs, 84(4), 714-735.

Rasiah, R. (2012). Beyond the Multi-Fiber Agreement: How are workers in East Asia faring? Institutions and Economies, 4(3), 1-20.

Rasiah, R., \& Nazeer, N. (2015). The state of manufacturing in Pakistan [Special edition]. Lahore Journal of Economics, 20, 205-224.

Rasiah, R., \& Nazeer, N. (in press). Comparing industrialization in Pakistan and the East Asian economies [Special edition]. Lahore Journal of Economics, 21.

Reinert, E. S. (2007). How rich countries got rich... and why poor countries stay poor. London: Constable.

Rodrik, D. (2007). One economics, many recipes: Globalization, institutions and economic growth. Princeton, NJ: Princeton University Press.

Rowthorn, B., \& Wells, J. R. (1987). Deindustrialization and foreign trade. Cambridge: Cambridge University Press.

Sarmad, K. (1992). External shocks and domestic adjustment in Pakistan 1970-1990. Pakistan Development Review, 31(4), 857-869. 
Sayeed, A. (1995). Political alignments, the state and industrial policy in Pakistan: A comparison of performance in the 1960s and 1980s. Unpublished PhD thesis, University of Cambridge, UK.

Smith, A. (1776). An inquiry into the nature and causes of the wealth of nations. London: Methuen.

Wade, R. (1990). Governing the market: Economic theory and the role of government in East Asian industrialization. Princeton, NJ: Princeton University Press.

Wizarat, S. (2002). The rise and fall of industrial productivity in Pakistan. Karachi: Oxford University Press.

Young, A. A. (1928). Increasing returns and economic progress. The Economic Journal, 38(152), 527-542.

Zaidi, S. A. (2005). Issues in Pakistan's economy (2nd ed.). Karachi: Oxford University Press. 